\begin{tabular}{|c|c|c|c|}
\hline Agar colony. & surface \& bottom small. & ditto. & ditto (starch agar) \\
\hline Potato. & $\begin{array}{l}\text { vellow, moist, potato } \\
\text { browned. }\end{array}$ & $\begin{array}{l}\text { gray, white, moist, } \\
\text { potato no change. }\end{array}$ & $\begin{array}{l}\text { yellow, poteto no } \\
\text { change. }\end{array}$ \\
\hline Milk. & $\begin{array}{l}\text { acid, coagulation, in } 5 \\
\text { days, no digestion, } \\
\text { reduce litmus. }\end{array}$ & $\begin{array}{l}\text { acid-coagulation in } 3 \\
\text { days, wheyed, gas, } \\
\text { reduce litmus. }\end{array}$ & $\begin{array}{l}\text { slight acid coagulation } \\
\text { in } 3 \text { days, wheyed, gas. }\end{array}$ \\
\hline Indol. & - & positive. & negative. \\
\hline Catalase. & - & positive. & negative. \\
\hline $\begin{array}{l}\text { Methyl acetyl } \\
\text { carbinol. }\end{array}$ & - & negative. & negative. \\
\hline Best $\mathrm{N}$ source. & $\longrightarrow$ & albumin.* & peptone. \\
\hline $\begin{array}{l}\text { Fermentation of } \\
\text { Carbohydrates. }\end{array}$ & $\begin{array}{l}\text { starch, hemicellulose, } \\
\text { glucose, xylose. }\end{array}$ & $\begin{array}{l}\text { starch, hemicellulose, } \\
\text { raffinose, glucose, lactose. } \\
\text { maltose, mannose, galac- } \\
\text { tose, fructose, sucrose, } \\
\text { xylose, arabinose, salicine. }\end{array}$ & ditto. \\
\hline
\end{tabular}

The photographs, in original paper, showing the vegetative cells, sporangia, flagella and fermentation of the filter paper in the test-tubes are accompanied.

\title{
STUDIES ON OYSTERS (I).
}

\section{CONSTITUENTS OF OYSTERS.}

By

Wataru. SHimiozo.

(Received July, 28 th., 1929.)

These chemical studies on the two kinds of Japanese oysters, Ostrea gigas - Thumb. \& Ostred denselamellosa Lisch. were inangurated in May 1926, extending over two years. The results thus produced are as follows:

1. As for the ratio of the amount of flesh to shell, the Ostrea gigas has a higher value, though relatively, than the Ostrea denselamellosa. The flesh of the latter is wasted especially in summer.

2. The analytic results of the flesh show that the $O$. denselamellosa contains much more nitrogen than $O$. gigas, but on the contrary, with regard to the quantities of the other elements-ash, soluble matters in ether and alcohol, glycogen-, the former is inferior to the latter. 
The O. gigas, which lives in less salty water, contains very large quantity of ash; this fact seems to indicate that it has large amonnt of mineral substances with the rapid growth of the shell.

These oysters contain much more glycogen than the other marine shells; but this glycogen, of course, is not always constant in the different seasons when they are collected, and also it will be properly supposed that it is changeable every moment when they are being stored, because it is a storing substance like fat or oil.

3. The ash of oysters was analysed and the following results have been obtained.

In $100 \mathrm{~g}$, of ash.

$\begin{array}{lcc} & \text { Ostrea gigas, } & \text { Ostrea denselamellosa. } \\ \text { Carbon } & 0.593 & 0.0 \\ \mathrm{Sand} \& \mathrm{SiO}_{2} & 5.897 & 4.530 \\ \mathrm{SO}_{3} & 3.827 & 7.042 \\ \mathrm{~K}_{2} \mathrm{O} & 23.148 & 16.281 \\ \mathrm{Na}_{2} \mathrm{O} & 16.799 & 18.914 \\ \mathrm{Fe}_{2} \mathrm{O}_{3} & 3.320 & 2.043 \\ \mathrm{CaO} & 4.495 & 5.783 \\ \mathrm{P}_{2} \mathrm{O}_{5} & 30.502 & 21.564 \\ \mathrm{MgO} & 4.945 & 4.534 \\ \mathrm{Mn} & 0.134 & 0.190 \\ \mathrm{Cl} & 1.769 & 15.248\end{array}$

These results prove that the chlorine-content in the ash of the $O$. gigas is very deficient, but the phosphoric acid content is remarkably rich. From the above, most of the phosphoric acid in the O. gigas may be said to have taken the chlorine's place for an anion. The potash is one of the predominant constituents in the ash, and exists, it seems, mostly in the form of the phosphate in the oysters.

4. The nitrogen of the extract of the flesh with ether and alcohol was respectively measured and the various forms of nitrogen in the residue were also determined :-

Total nitrogen.

Nitrogen soluble in ether.

Nitrogen soluble in alcohol.

Nitrogen not dissolved in conc. $\mathrm{HCl}$,

Nitrogen dissolved in conc. HCl.

Amide nitrogen.

Humin nitrogen.

Mono-amino nitrogen.

Di-amino nitrogen.

Arginin nitrogen.
In $100 \mathrm{~g}$. of the anhydrous oysters.

$\begin{array}{cc}\text { Ostrea gigas. } & \text { Ostrea denselamellosa } \\ 7.135 & 9.600 \\ 0.127 & 0.445 \\ 1.601 & 1.692 \\ 0.257 & 0.217 \\ 5.220 & 7.350 \\ 0.409 & 0.677 \\ 0.148 & 0.150 \\ 3.481 & 4.977 \\ 1.427 & 2.060 \\ 0.567 & 0.825\end{array}$




$\begin{array}{lll}\text { Cystin nitrogen. } & 0.339 & 0.460 \\ \text { Histidin nitrogen. } & 0.440 & 0.619 \\ \text { Lysin nitrogen. } & 0.081 & 0.158\end{array}$

From these results, it will be concluded that the flesh of the oysters has a high nutritive value, as it contains Histidin, Cystin, Lysin in abundance.

\title{
STUDIES ON OYSTERS (II).
}

\section{THE OPTIMUM HYDROGEN ION CONCENTRATION \\ AND THE OPTIMUM TEMPERATURE OF THE GLYCOGENASE OF THE OYSTER.}

\section{By}

\author{
Wataru. SHimidzu. \\ (Received Sept, 6th, 1929.)
}

The powerful, yet unstable, glycogenase were isolated from the flesh of Ostrea gigas, and the various characters on its activity were investigated :

1). The optimum hydrogen ion concentration for the glycogenase action of the oyster in acetic-soda buffer was found to be at or near $\mathrm{pH} 5.0$, and in citrate buffer it was at $\mathrm{pH} 5.5$. These experiments were carried out under the identical conditions, viz. the enzyme was allowed to act upon glycogen solutions at $30^{\circ} \mathrm{C}$ for 48 hours, and at the end of the time their reducing powers were determined. So the above results prove that the optimum hydrogen ion concentration is varied with the buffer solution used.

But, on the other hand, when phosphate buffer was used, the optimum hydrogen ion concentration was shown to be at least as high as that indicated by $\mathrm{pH} \quad 6.5 \sim 6.8$ at the first hour; but its maximum point being moved little by little with time, it was shown to be at $\mathrm{pH} 5.5$ after 24 hours, and lower than it after 48 hours.

2). And its reaction velocity was turned down with time. From these results, we can suggest these two facts.

The first-, if we grant that the enzyme is active but easily destroyed at or near $\mathrm{pH} 6.8$; and at or near $\mathrm{pH} 5.0$, it is less active and it is dulable ; thus, as a necessary consequence, we can understand that the diastatic products are greater at the higher hydrogen ion concentration in the long run. The second-, it is quite possible that there are really two or more amylases 